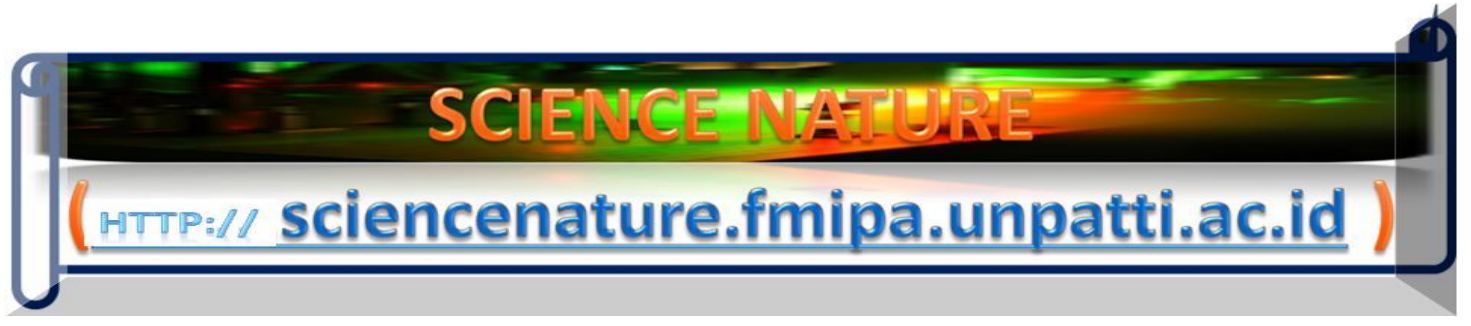

Science Nature 2(1), pp.057-065 (2019)

e-ISSN 2654-6264

DOI: https://doi.org/10.30598/SNVol2Iss1pp057-065year2019

\title{
The Implementation of High School Local Content Learning in Babar Island
}

\author{
Juliaans Marantika ${ }^{1}$, Tanwey Gerson Ratumanan ${ }^{2 *}$, and Effilina Kissiya ${ }^{3}$ \\ Pattimura University \\ julians.marantika@yahoo.com ${ }^{1}$, gratumanan@yahoo.com²
}

\begin{abstract}
Received : January 16, 2019
Revised : January 31, 2019

Published : March 11, 2019
\end{abstract}

Copyright @ All rights are reserved by J. Marantika, T.G. Ratumanan, E. Kissiya

Corresponding author: "Email: gratumanan@yahoo.com 


\section{Abstract}

This study deals with the effort of obtaining information about aspects of practicality or implementation of lesson plans and local content textbooks, the quality of textbooks, and the responds of teachers and students toward local content and its application at the school in Babar island. The research was conducted at Babar State High School 1 using descriptive analytical method. Data was collected using observation and questionnaire techniques. Observations were made to obtain information related to the implementation of classroom learning. The questionnaire was used to explore teachers and students perspective about textbooks. The research results indicate that learning activities happened smoothly. The quality of the textbook used is quite good and has a good level of readability. The response of teachers and students to teaching books is highly positive. The teaching material provided is in accordance with the needs of the school, especially students. The enthusiasm of students is seen in the whole learning activities, both in face to face and in completing tasks (homework).

Keywords: Implementation, Local Content Learning, Babar Island

\section{ARTICLES}

\section{Introduction}

Babar islands is one of the cluster islands in the Southwest Maluku Regency [1] which is grouped as the outer islands of Indonesia (PP No 6 of 2017). One of the largest islands of the cluster is Babar Island. In relation to the development of Masela block, this island is very strategic. Besides being located inside the Masela block area, Babar Island is also the largest and closest to the Masela block area. The availability of land for the construction of refineries, housing and development of the petrochemical industry, fertilizer industry, etc. is relatively sufficient. Further, the availability of clean

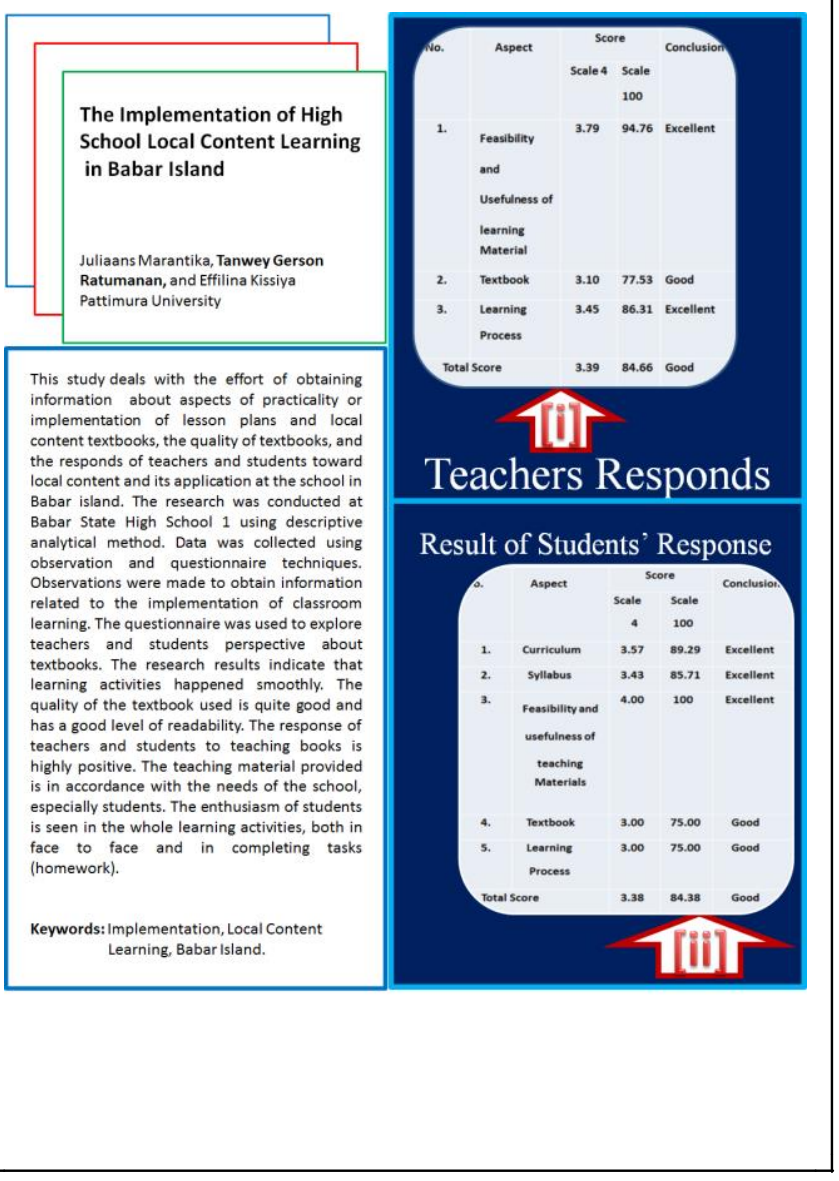

water is also relatively better compared to the surrounding islands. Thus, Babar Island has the potential to be used as a center for the development of upstream industries and downstream industries in the Masela block.

The process of managing industries both upstream and downstream in this region will on the one hand have a positive impact on the economic growth of the community. On the other hand, the economic growth of the community and the migration of workers from various regions will have an impact on the changing dynamics of the socio-cultural life of the surrounding community. The industrialization process has a huge influence on the social system and structure of society, especially the basic way of life. The direct impact is a 
change in the pattern of employment relations from traditional to modern [2] whereas according to Setiawati (2002) in Ref. [3] village communities are individuals and families that form a social group that is interconnected with each other and bound with a lifestyle that is normatively governed by traditional norms, values and institutions. This condition needs to be anticipated considering the emergence of a variety of multidimensional problems in the coastal areas that originate from overlapping policy implementation until the social conflicts of communities at the community and individual levels [4] or mentioned by Beatley et al in Ref. [5] as phenomena of

The Tragedy of The Common.

Considering that Babar islands community is generally a traditional society that still bounds and maintains family pattern of life, the possibility of threat of fading cultural values, the development individualism attitude, consumerism, westernization and hedonism needs to be anticipated [6]. One of the strategies needed to anticipate this is through education. The reason is that education is the most effective way for increasing regional resources. The results of study by Inkeles and Smith (1976) as shown in Ref. [7] and cited by Ratumanan, show that education provides a three-fold contribution to the development of human resources when compared to other businesses such as capital and technology. Improvement through education can be done through development and implementation of local content curriculum.

Covering the development of local wisdom and its enrichment as local content in the curriculum of local content is expected to be able to develop the ability of the younger generation to endure social impacts that will emerge along with the development of upstream industries and downstream industry in the management of the Masela block. Adler in Ref. [8] emphasizes the importance of managing diversity (cultural diversity) in a togetherness. While the Ministry of National Education [9] describes that the application of Local
Content is expected to provide knowledge, skills and behavior to students so that they have extensive insight about regional environment and the needs of the community in accordance with applicable values / rules and take part in supporting the continuity of regional and national development.

To support the implementation of the local content curriculum that has been developed, a learning design that includes syllabus, and local content textbooks for junior and senior high schools that highlight local wisdom and culture was prepared. The model of learning developed refers to Plomp model in Ref. [10], which consists of 5 (five) phases, namely (1) initial study (preliminary investigation), (2) design, (3) realization / construction, (4) test, evaluation, and revision, and (5) implementation.

The design of the learning tools is intended not only to be used as a supporting component of the local content curriculum, but also provides local content learning tools in schools as one of the requirements stipulated in the Law of National Education System and the 2013 curriculum [11] which requires schools to teach local content curriculum in each school. This study aims at obtaining an overview of whether learning devices, especially textbooks have been developed to meet the demands of applying local content curricula in SMP and SMA on Babar archipelago. To study its relevance to the needs and accordance with the anticipation efforts of the social impact of Masela block development towards junior and senior high school students on Babar archipelago Southwest Maluku Regency. To know its level of implementation and the response of teachers and students to the implementation of the intended curriculum.

\section{Research Method}

This research is descriptive analytical research. According to Sugiyono in Ref. [12] descriptive method is a method that serves to describe or give an overview of 
the object under study through data or samples that have been collected as they are without doing analysis and making conclusions that apply to the public.

The research was carried out in the State High School 1 of Babar islands class X. Data was obtained through direct observation in the classroom conducted by 1 (one) supervisor and 1 (one) research staff by referring to observation instruments or guidelines. Supervisors and research personnel observed the learning process, recorded every activity and interaction that occurs between the teacher and students, and between students and students. In addition to primary data through observation, research also obtained secondary data through information. The questionnaire was given to teachers and students to find out their response towards the application of local content. The teachers' response in the questionnaire includes (1) the curriculum, (2) syllabus, (3) feasibility and benefits of learning material, (4) textbooks, (5) learning, and (6) notes on each chapter of the textbook and suggestions for revision. While the students' response in the questionnaire includes: (1) the feasibility and benefits of learning material, (2) learning, and (3) notes on each chapter of the textbook and suggestions for revision.

\section{Results and Discussion}

As explained earlier, the research was conducted at grade ten of State Senior High School 1 Babar islands located in Tepa. Prior to the research, the teachers who were going to carry out local content learning activities in the classroom and the supervisors who were going to conduct observations were debriefed. Debriefing was done by discussing the objectives of developing local content and how the learning process will be carried out. For teachers, the scope of local content material was expected to be mastered by students, how to manage local content learning, and what tasks and activities should be carried out by students. In addition, textbooks, syllabus, and examples of teaching and learning implementation plan were given to be used as a reference for teachers in preparing lesson plans. Meanwhile for observers, the discussion was focused on the mechanism of observation procedures, the instrument used, how it is filled, and the expected results.

Based on the debriefing given to the teachers, the entire learning process was done smoothly according to the developed lesson plan. This was seen in the management of teaching and learning process conducted by the teacher and the response of students. In general, the students paid serious attention to the whole learning activities. Learning material for local content, such as traditional clothing, games, and houses that are loaded with cultural values. The teaching materials in fact attract students' attention because throughout the observation on Babar archipelago these items were not seen any more in the community daily life due to modernization impact.

The teacher's response towards the local content learning indicates that aspects of local content in the developed curriculum were highly appreciated. The teacher mentioned that the curriculum was clear, well structured, adequate, and can be implemented in high schools in Babar archipelago. Besides, they also asserted that the developed textbooks and subject matter were important for students and it was arranged according to the level of students' cognition. It was also useful to increase students' knowledge, foster awareness of preserving local culture, and have an impact on students' character building. 
Table 1. Teacher's Responds.

\begin{tabular}{|c|c|c|c|c|}
\hline \hline \multirow{2}{*}{ No. } & \multirow{2}{*}{ Aspect } & \multicolumn{2}{|c|}{ Score } & \multirow{2}{*}{ Conclusion } \\
\cline { 3 - 4 } & & Scale & Scale & \\
\hline 1 & Curriculum & 3.57 & 89.29 & Excellent \\
\hline 2 & Syllabus & 3.43 & 85.71 & Excellent \\
\hline 3 & Feasibility & 4.00 & 100 & Excellent \\
& and & & & \\
& $\begin{array}{c}\text { usefulness of } \\
\text { teaching }\end{array}$ & & & \\
\hline 4 & Materials & & & \\
\hline 5 & Textbook & 3.00 & 75.00 & Good \\
\hline & Process & 3.00 & 75.00 & Good \\
\hline & Total Score & 3.38 & $\mathbf{8 4 . 3 8}$ & Good \\
\hline
\end{tabular}

In addition to the positive response, the teacher also provided some notes for improvement. The inputs given in relation to the improvement of the textbooks were: (1) The use of several terms in traditional homes, such as inalyewna; (2) The use of the word "Kalwedo" to address people which is different from one village to another, such as in the village of Tela uses "Twan", Imroing uses "Twano"; (3) Considering that the culture or Tradition of Nweleya is now no longer found on Babar Island specifically and Babar Islands in general, it is necessary to do an action of plan for development and introduced to the community; (4) The same thing also needs to be done for songs from Babar archipelago that need to be developed by writing more songs.

A positive response was also reflected in the implementation of learning process. The learning process in the classroom went well and smoothly. There was dynamic interaction between teachers and students, as well as between students. Students were enthusiastic in reading the learning material in the textbook, discussing it in group, actively working on the questions or assignments given, and presenting the results of group discussions. The follow up tasks given by the teacher to explore further information can be carried out by students. Some of students' work results are shown in the following figure:

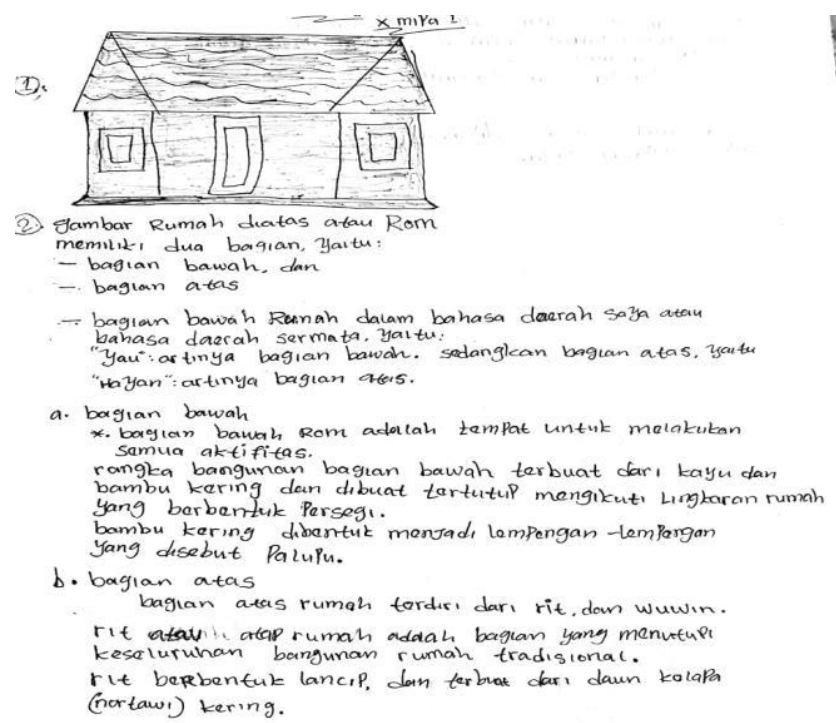

Figure 1. Working result of Robert Tahanora.

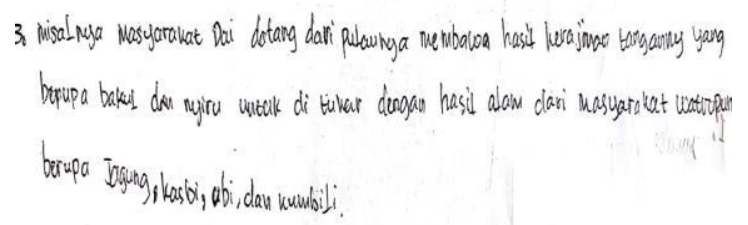

Figure 2. Working reslut of Julius Aktawalora explaining barter example fromhis village

In addition to the positive response from the teacher, the results of observations, interviews, and questionnaires filled out by students also indicated that they strongly accepted the existence of the local content curriculum. The students were motivated to know more about their local culture which is part of their identity. From the analysis of students responses from the questionnaire, it was obvious that the learning material was considered highly relevant to the needs (score 100), 
useful (score 97.62), and fostering awareness of the importance of preserving cultural values (score 97.62). A relatively low score relates to students' responses to tasks or activities that must be done (score 60.71) and doing practice questions (score 67.86).

The results of analysis of student responses is presented in the following Table 2.

Table 2. Result of Students' Response

\begin{tabular}{|c|c|c|l|l|}
\hline \hline \multirow{2}{*}{ No. } & \multirow{2}{*}{ Aspect } & \multicolumn{2}{|c|}{ Score } & \multirow{2}{*}{ Conclusion } \\
\cline { 3 - 5 } & & Scale 4 & Scale & \\
\hline 1. & Feasibility & 3.79 & 94.76 & Excellent \\
and & $\begin{array}{l}\text { Usefulness of } \\
\text { learning }\end{array}$ & 3.10 & 77.53 & Good \\
\hline 2. & Textbook & 3.45 & 86.31 & Excellent \\
\hline 3. & Learning & & & \\
\hline & Process & 3.39 & 84.66 & Good \\
\hline
\end{tabular}

From the responses of students through questionnaire, there were also some inputs or suggestions that need to be considered. The suggestions were as follows: (1) Activities to make traditional houses are difficult because there is no more traditional houses on Babar Island; (2) There are several names or terms that need to be revised, namely: Tiarka should be changed to Diarki, Telaa should be changed to Tela, Sermatang should be changed to Sermata.

The purpose of developing a local content curriculum was to help the schools to conduct local content learning as it is required in the current national curriculum. Besides, it is also an effort to embed Babar community cultural values for students in anticipating the development of science and technology in this global era, especially the presence of the Masela block. The teacher's excellent response to the structure of the curriculum, syllabus and textbooks developed illustrates that aspects of local content in the curriculum developed have been in accordance with the school's needs for local content. Moreover, it is supported by systematic learning steps that enable teachers to carry out classroom learning easily. This of course can overcome the obstacles that have been experienced by the schools due to the unavailability of special local content curricula as learning guidelines. The results of the study illustrate that the curriculum and learning tools developed have fulfilled the requirements to be used in the schools.

The results of the study also illustrate that the application of local content learning was well implemented. The development of a syllabus that refers to basic competencies and clear achievement indicators have made it easy for the teachers to develop lesson plan. The learning steps that have been contained in the next learning plan can be implemented in the classroom. This indicates that the curriculum and learning tools developed have relatively high levels of implementation.

An excellent assessment of learning material both from the teacher and the students indicates that the subject matter has been prepared in accordance with students' cognition level as well as useful to increase the knowledge of students; More than that, it is very useful to foster awareness of preserving local culture while at the same time having an impact on students' character building. The attractiveness and curiosity of the students towards local content teaching material that contains local wisdom and living traditions of the Babar community indicate a positive perspective. The cultural values that have so far been forgotten due to modernization got its moment to be revived especially among the younger generation. This indicates an expectation that learning local content in schools can serve as a way to preserve Babar's cultural values for the younger generation. Thus both the younger generation and the community can become increasingly aware of 
the importance of cultural wealth and the values contained in it. Increasing awareness of cultural identity will motivate the Babar people to reorganize their lifestyle by always making Babar's culture and local wisdom their way of life.

The results showed that the local content curriculum developed had met the quality criteria, according to the criteria given by Nieveen (1999: 127-128) as depicted in Ref. [13]. Nieveen mentioned that the quality of a prototype is determined by aspects of validity, practicality, and effectiveness. The curriculum of local content, syllabus, and textbooks of class VII and X that are developed meet the aspects of validity. The results of classroom observations indicate that learning can be carried out according to the developed learning tools (syllabus, lesson plans, and textbooks). Thus the curriculum and learning tools fulfill the practicality aspect. The teachers and students respond excellent and good to the textbooks and local content learning. This means that the curriculum and learning devices fulfill the effectiveness aspects.

Besides the responses of teachers and students, local content learning materials, such as traditional clothes, games, and houses that are loaded with cultural values attract the community's attention. According to some community leaders on Babar Island, the existence of traditional houses, and games have been replaced with modern houses and games. This indicates that, in general, there has been an erosion of people's understanding of their cultural values. The community is not aware of the importance of traditional wealth and the values contained in it as one of the cultural identity and wealth of the people in Babar Islands. This condition certainly needs serious attention from policy makers, customary leaders, and community leaders. Strategic efforts are needed to reduce or prevent the symptoms of acculturation in the Babar community, especially the younger generation.

\section{Conclusion}

The curriculum development of local content is not only aimed at being used as a reference for implementing local content learning in schools, but at the same time providing students with knowledge, skills, and attitudes and behavior formation so that they have a broad, steady insight into their environment and the culture of the community and region. It is hoped that the values of local wisdom can be conserved and managed wisely for the benefit of self-development, regional development and supporting national development. Incorporating efforts to preserve the cultural values and local wisdom in the formal education system is a strategic step. The reason is through formal education channels especially junior and senior high schools, the process of reintroducing and internalizing these values can be maximally linked.

The positive perceptions of teachers, students and the local community about the presence of the local content curriculum and its implementation gave light for the effort of conserving the culture. Therefore, there should be a policy taken by policy makers in the regions especially at the district government in accelerating the use of local content curricula that have been developed in the Babar Island sub-district schools. In addition to policy makers at the district level, community support is also needed, especially the village government, customary leaders, community leaders, and parents to support the school's efforts by encouraging the application of cultural values and local wisdom throughout the daily life patterns of the Babar community so the process of cultural values internalization is obtained during the learning process gain support in the environment where the child live.

\section{Acknowledgement}

The authors would like to thank Indonesia Ministry of Higher Education for their supports in this work. 


\section{References}

[1]. Ralahalu Karel Albert. 2008. The Wonderful Island Maluku, Membangun Kembali Maluku dengan Nilai-nilai dan Khasanah Lokal, serta Prinsip Enterpreneurial Government, Beragam Potensi dan Peluang Investasi. Gibbonbooks. Jakarta.

[2]. Ibrahim, J.T 2002. dalam Noviani Nurkolis . Dampak Keberadaan Industri Terhadap Ekonomi Masyarakat Serat Lingkungan Industri https://s3.amazonaws.com/academia.edu.docume nts/33456176/dampak-industri-terhadap ekonomi masyarakat dan lingkungan industri/ (Online) . diakses pada tanggal 9 Maret 2019

[3]. Setiawati 2002 dalam Fikry Zuledy. Sosiologi Pembangunan: Dampak dari Industrialisasi Wilayah Pedesaan. https://www.academia.edu/15550379/sosiologi _pembangunan_dampak_dari_industrialisasi_wi layah_pedesaan/ (Online). diakses pada tanggal 9 Maret 2019

[4]. Kay, R. dan Alder, J. 2005. Coastal Planning and Management. New York, USA: Taylor and Francis Group.

[5]. Beatley, T., Brower, DJ., Schwab, AK. 2002. An Introduction To Coastal Zone Management (Second Edition). Washington DC, USA: ISLAND Press.

[6]. Ratumanan, T. G, dkk. 2017. Pengembangan Kurikulum Muatan Lokal:Antisipasi Dampak Sosial Pengelolaan Blok Masela Pada Siswa Smp Dan Sma Di Pulau Babar Kabupaten Maluku Barat Daya.Laporan Penelitian Unggulan Perguruan Tinggi.

[7] Inkeles, A., and Smith, D.H. 1976. Becoming Modern: Individual Change in Six Developing Countries, President and Fellows, Harvad Collage, Cambridge

[8]. Adler, N. 2008. International Dimension of Organizational Behavior. USA: Thomson-SouthWestern.
[9]. Depdiknas. 2008. Pengembangan Muatan Lokal. Jakarta: Direkorat Pembinaan Sekolah Menengah Atas.

[10]. Plomp, Tjeerd. 1997. Education and Training System Design. $\quad$ Enschede, The Netherlands: University of Twente.

[11]. Depdiknas. 2010. Petunjuk Teknis Pengembangan Muatan Lokal. Jakarta: Depdiknas.

[12]. Sugiyono. 2009. Metode Penelitian Kuantitatif, Kualitatif dan R\&D, Bandung : Alfabeta.

[13]. Nieveen, Nienke. 1999. Prototyping to Reach Product Quality. In Jan Van den Akker, R.M. Branch, K. Gustafson, N. Nieveen, \& Tj. Plomp (Eds.). Design Approaches and Tools in Education and Training (pp. 125-135). Dordrecht, The Netherlands: Kluwer Academic Publishers. 


\section{"Corresponding Author Brief CV}

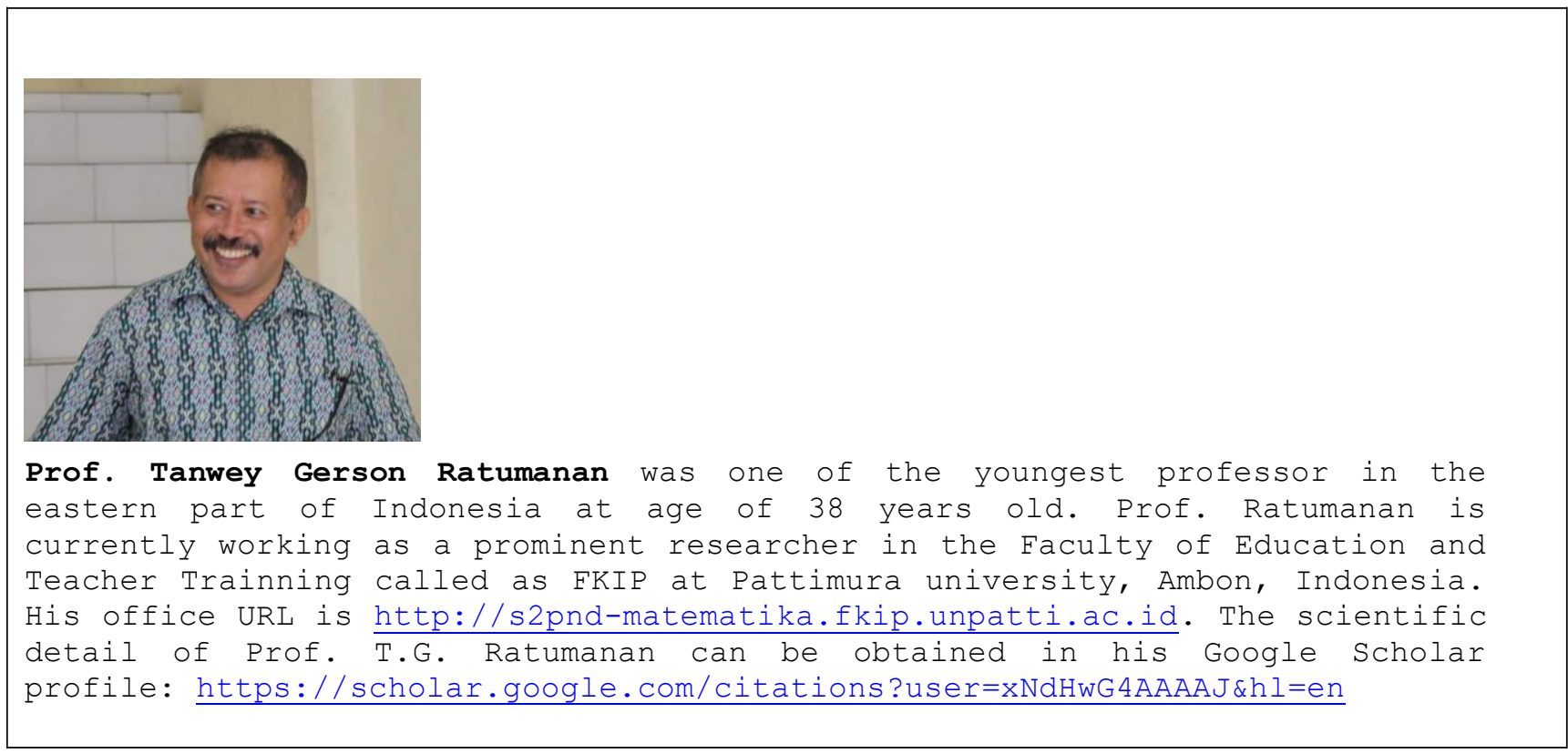

E-ISSN: 2654-6264

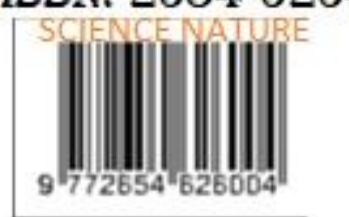

